\title{
Öğretmen Özyeterlik İnancı Ölçeği Geçerlik ve Güvenirlik Çalışması
}

DOI: $10.21666 /$ muefd.319209

\author{
İbrahim COLAK \\ Muğla Sttkı Koçman Üniversitesi,e-posta: ibrhmcolak@gmail.com \\ Y1lmaz İlker YORULMAZ \\ Muğla Sitkı Koçman Üniversitesi,e-posta: yilkeryorulmaz@gmail.com \\ Yahya ALTINKURT \\ Muğla Sitkı Koçman Üniversitesi, e-posta: yaltinkurt@gmail.com
}

\begin{abstract}
$\ddot{O} z$ et
Bu araștırmanın amacı, öğretmenlerin özyeterlik inançlarını belirlemede kullanilabilecek bir ölçme aracı geliştirmektir. Araştırmanın çalışma grubunu, ilkokul, ortaokul ve lise öğretmenleri olușturmaktadır. Ölçeğin yapı geçerliği için açımlayıcı (AFA) ve doğrulayıcı (DFA) faktör analizi yapılmıştır. AFA sonucunda, Akademik Özyeterlik, Mesleki Özyeterlik, Sosyal Özyeterlik ve Entelektüel Özyeterlik olmak üzere 27 maddeli ve dört faktörlü bir yapı ortaya çıkmıştır. Bu yapı DFA ile doğrulanmıştır. DFA ile elde edilen bulgular değerlendirildiğinde $\chi^{2} /$ sd oranı 2.12 bulunmuş̧tur. DFA ile hesaplanan diğer uyum iyiliği indeksleri şöyledir: $G F I=.85, A G F I=.82$, $R M S E A=.06, R M R=.03, S R M R=.06, C F I=.97, N F I=.95, N N F I=.97$. Sonuç olarak, ögretmenlerin özyeterlik inançlarını belirlemede kullanılabilecek psikometrik özellikleri yeterli, geçerli ve güvenilir bir ölçek geliştirilmiștir.
\end{abstract}

Anahtar Kelimeler: Özyeterlik ölçeği, özyeterlik, ögretmen

\section{The Validity and Reliability Study of Teacher Self-Efficacy Beliefs Scale}

\begin{abstract}
The purpose of this study is to develop a scale to be used to determine the self-efficacy beliefs of teachers. The study group of the research consists of teachers of primary, secondary and high schools. Explanatory (EFA) and confirmatory (CFA) factor analyses were conducted to assess the structural validity of the scale. The results of the EFA showed that the scale was comprised of four factors, namely, Academic Self-Efficacy, Professional SelfEfficacy, Social Self-Efficacy, and Intellectual Self-Efficacy. The scale consisted of 27 items. CFA revealed a $\chi^{2} / d f$ ratio of 2.12. Other goodness for fit indexes computed by $C F A$ were: $G F I=.85, A G F I=.82, R M S E A=.06$, $R M R=.03, S R M R=.06, C F I=.97, N F I=.95, N N F I=.97$. As a result, a valid and reliable scale with sufficient psychometric features was developed that could be used to determine the self-efficacy beliefs of teachers.
\end{abstract}

Key Words: Self-efficacy scale, self- efficacy, teacher

Özyeterlik kavramı ilk olarak Bandura'nın 1977 yılındaki "Self-efficacy: Toward a Unifying Theory of Behavioral Change" adlı makalesinde yer almıștır. Daha sonra Bandura (1997), özyeterlik kavramını sosyal-bilişsel kuram çerçevesinde geliştirmiştir. Bandura (1997) özyeterliği, bireyin sahip olduklarıyla belirli durumlarda neleri yapabileceğine ilişkin inancı olarak tanımlamaktadır. Benzer șekilde Stajkovic ve Luthans (2002) özyeterlik inancını, insanların belirli bir durumda bir iși geçekleștirebilmelerine ilişkin kendilerine olan güveni olarak tanımlamaktadır. Ancak özyeterlik, kişinin sadece belirli yeteneklere sahip olması ve bunları performansa dönüş̧ürebilmesi değildir. Özyeterlik, bilişsel, sosyal, 
duygusal ve psiko-motor becerilere sahip olmanın yanı sıra, zor şartlar altında bunları uyumlu bir şekilde bir araya getirmeyi gerektirmektedir (Bandura, 1997).

Özyeterlik inanc1, bireylerin harekete geçmelerinde önemli bir etkiye sahiptir. Eğer insanlar istedikleri sonuçları elde edeceklerine inanmazlarsa, harekete geçmek için başka etkenler olsa da yeterli derecede güdülenmeyeceklerdir (Bandura, 1986). Çünkü özyeterlik inancı, bireylerin seçimlerini, amaçlarını ve zor durumlarda gösterecekleri çabay1 etkilemektedir (Lunenburg, 2011). Yani özyeterlik inancı, bireylerin motive olmasını sağlayan psikolojik bir mekanizmadır (Stajkovic ve Luthans, 2002). Bu görüşe göre özyeterlik inancı, insanların davranışlarıyla istedikleri sonuçlara ulaşma ve çevrelerini etkileme kapasitelerine olan inançlarını ifade eder.

Bandura (1993), özyeterliğin bireyin davranışları üzerindeki kontrolünün yanı sıra düşünce sürecinin düzenlenmesini, motivasyonu, duygusal ve psikolojik durumları da kapsadığını belirtmektedir. Dolayısıyla benzer yeteneklere sahip farklı kişiler veya farklı şartlar altında aynı kişi, özyeterlik inancındaki değişikliklere bağlı olarak düşük, yeterli veya yüksek performans sergileyebilir. Bir başka deyişle özyeterlik inanc1, bireyin yeteneklerinin doğrudan sonucu olmayan, ancak içinde bulunduğu durum ve sahip olduğu becerilerle bireyin ne yapabileceğini belirleyen içsel bir motivasyondur.

Özyeterlik inancı, bireyin kişisel ve durumsal etmenleri öznel bir şekilde algılaması ile oluşmaktadır (Stajkovic ve Luthans, 2002). Bu noktada bireyin özyeterlik inancının oluşmasında farklı durum ve olaylar etkili olabilmektedir. Bandura (1997), özyeterlik inançlarını oluşturan dört temel etmenden bahsetmektedir. Bunlar, kişinin kendi deneyimleri, dolaylı deneyimler, sözel ikna, fizyolojik ve psikolojik uyarılmadır. Kişinin kendi deneyimlerinin özyeterlik inancında daha güçlü bir etkiye sahip olduğu söylenebilir. Çünkü bireyler, gelecekteki performanslarını, geçmiş performanslarını değerlendirerek öngörebilirler (Bandura, 1977). Ancak bu deneyimlerin özyeterlik inancina dönüşmesinde kişisel, sosyal ve durumsal etmenlerden etkilenen bilişsel süreçler önemli rol oynamaktadır (Bandura, 1997; Stajkovic ve Luthans, 2002).

Özyeterlik inancının oluşması ve yeterli düzeyde olması bireylerin davranışlarını, olaylara karşı bakış açılarını, amaçlarını ve başarılarını olumlu bir biçimde etkileyebilmektedir. Bunlar arasında en önemlisi özyeterliğin kişisel başarıya yaptığı katkıdır. Kişisel başarılar sadece yeteneklerin bir sonucu değil aynı zamanda bireyin bunları kullanmaya yönelik duyduğu özyeterlik inancının bir sonucudur (Bandura, 1993). Yeteneklerine ilişkin yüksek özyeterlik inancına sahip çalışanlar, belirledikleri yüksek hedeflere bağl1lık duyar ve başarılı sonuçlara ulaşmak için yeterli düzeyde çaba gösterirler. Ayrıca zor işlere, kaçınılması gereken tehditler olarak değil, başarılması gereken mücadeleler gözüyle bakarlar. Bu durum çabalarını zor ve belirsiz durumlarda bile sürdürmelerini sağlar. Yaptıkları işler için başarısızlık durumunda bile büyük çaba göstermeye devam eder ve bu işlere bağll1ık duyarlar. Çevrelerindeki olumsuzlukları ve tehditleri kontrol edebileceklerini düşünürler. Dolayısıyla daha az stres yaşar ve işlerini daha yüksek düzeyde başarıyla tamamlarlar. Ancak düşük özyeterliğe sahip çalışanlar, kendilerini motive etmekte zorlanma ve zorluklar karşısında kısa süre içerisinde çabalarından vazgeçme eğilimindedirler. Aynı zamanda bu çalışanlar başarı için gerekenleri yapabileceklerine dair şüphe duyar ve zorlayıcı işlerden kaçınırlar. Bu durum, onları genellikle başarısızlıkla karşı karşıya bırakır (Bandura, 1993, 1997; Stajkovic ve Luthans, 2002). Dolayısıyla özyeterlik inancı, çalışanların harekete geçmesinde ve bundan sonra çabalarına devam ettirmelerinde belirleyici bir rol oynamaktadır.

Öğretmenlerin öğretim sürecinde gösterdikleri çaba, neleri yapabileceklerine olan inançlarından önemli ölçüde etkilenmektedir (Bandura, 1997). Nitekim etkili öğrenmenin gerçekleşebileceği bir sınıf ortamının oluşturulması büyük ölçüde öğretmenlerin yeteneklerine ve öz yeterlik inançlarına bağlıdır (Bandura, 1993). Bu durum özyeterlik inancını öğretmenlik mesleği için önemli bir kavram haline getirmektedir. Öğretmenler özyeterlik inançları sayesinde sahip oldukları bilgi ve yeteneklerini zor şartlar altında üretken bir şekilde kullanarak önemli işler başarabilirler. Bandura (1993, 1997), öğretmenlerin yeteneklerinin ve özyeterlik inançlarının, öğrencilerin bilişsel ve akademik yeterliklerinin gelişimini sağlayacak öğrenme ortamlarının oluşumunda etkili olduğunu ifade etmektedir. Örneğin öğretmenlerin öğretimsel yeterliklerine olan inançları, sınıflarındaki etkinlikleri şekillendirmelerinde belirleyici bir rol oynamaktadır.

Yüksek düzeyde öğretimsel özyeterliğe sahip öğretmenler, öğrenmede zorluk çeken öğrencilerin yeterli çaba ile öğrenebileceği inancı taşırlar. Bu öğretmenler, aile desteğini sağlayabilir ve çevreninin 
öğretimsel süreçlerdeki olumsuz etkilerinin üstesinden gelebilirler. Diğer yandan, düşük düzeyde öğretimsel özyeterliğe sahip öğretmenler, öğrencilerin yeterli motivasyona sahip olmaması durumunda yapacak bir şeyin olmadığını ve çevrenin ve ailenin olumsuz etkileri karşısında öğrencileri etkileme gücüne sahip olmadıklarını düşünürler (Gibson ve Dembo, 1984). Dolayısıyla düşük özyeterlik inancına sahip öğretmenler, işlerindeki zorluklara karşı daha karamsar bir bakış açısıyla yaklaşmakta iken yüksek özyeterlik inancına sahip öğretmenler zorlukların üstesinden bir şekilde gelebilecekleri inancını taşımaktadırlar.

Alanyazın incelendiğinde öğretmenlerin yeterliklerini ölçmek için yapılan çalışmaların Gibson ve Dembo (1984) ile başladığı görülmektedir. Araştırmacılar, kişisel öğretim yeterliği ve genel öğretim yeterliği olmak üzere iki boyuttan oluşan 30 maddelik bir ölçek geliştirilmişlerdir. Emmer ve Hickman (1991) ise sınıf yönetimi, dış etkiler ve kişisel öğretim yeterliği olarak adlandırılan üç faktörlü öğretmen yeterliği ölçeğini geliş̧irmiştir. Tschannen-Moran ve Hoy (2001) tarafından geliştirilen "Öğretmen Yeterlik Ölçeği”, öğretimsel stratejilerde yeterlik, sınıf yönetiminde yeterlik, öğrenci katılımını sağlamada yeterlik olmak üzere üç faktörden oluşmaktadır. Ölçek hem 24 maddelik uzun bir forma hem de 12 maddelik kısa bir forma sahiptir. Bandura (2006) özyeterlik ölçeklerinin oluşturulması için bir rehber niteliğinde olan çalışmasında öğretmen özyeterliklerini ölçmeye yönelik örnek bir ölçek sunmaktadır. Bu ölçekte öğretmen özyeterlikleri 6 boyutta ele alınmıştır: (1) Karar vermeyi etkileme yeterliği, (2) öğretimsel yeterlik, (3) disiplin yeterliği, (4) veli desteğini alma yeterliği, (5) çevre desteğini alma yeterliği, (6) olumlu bir okul iklimi oluşturma yeterliğidir.

Türkiye'de öğretmenlerin özyeterlik inancını ölçmek için son zamanlarda uyarlanan ölçme araçları bulunmaktadır. Diken (2004), Gibson ve Dembo (1984) tarafindan geliştirilen, Guskey ve Passaro (1994) tarafından revize edilen “Öğretmen Yeterlik Ölçeği”ni Türkçeye uyarlamıştır. Açımlayıcı faktör analizi soncunda orijinalinde 21 madde olan ölçeğin, bireysel öğretim yeterliği ve genel öğretim yeterliği olmak üzere iki faktörden ve 16 maddeden oluştuğu sonucuna ulaşılmıştır. Cerit (2010), Gibson ve Dembo (1984) tarafından geliştirilen ölçeği Türkçeye uyarlamıştır. Çalışmanın örneklemini sınıf öğretmeni adayları oluşturmuştur. Bu çalışmada, orijinal ölçekteki kişisel öğretim yeterliği ve genel öğretim yeterliği faktörlerinin yanı sıra mesleki bilgi yeterliği adında yeni bir faktör ortaya konmuştur. Çapa, Çakıroğlu ve Sarıkaya (2005), Tschannen-Moran ve Hoy (2001) tarafından geliştirilen Öğretmen Özyeterlik Ölçeğini Türkçeye uyarlamışlardır. Öğretmen adaylarından toplanan verilere doğrulayıcı faktör analizi uygulanmış ve ölçeğin öğretimsel stratejilerde yeterlik, sınıf yönetiminde yeterlik, öğrenci katılımını sağlamada yeterlik başlıklı üç faktörlü yapısı doğrulanmıştır. Taşkın ve Hacıömeroğlu (2010), Dellinger, Bobbett, Olivier ve Ellet (2008) tarafından geliştirilen “Öğretmen Özyeterlik İnanç Ölçeği”ni Türkçeye uyarlamıştır. Öğretmen adaylarından toplanan veriler ile ölçeğin yapı geçerliği için açımlayıcı ve doğrulayıcı faktör analizi yapılmıştır. Bu analizler sonucunda planlama ve öğrenmeyi geliştirme, olumlu sınıf ortamı oluşturma, etkili öğrenme-öğretme süreci, bireysel farklılıklar ve akademik gelişim faktörlerinden ve 29 maddeden oluşan bir yapı ortaya konmuştur. Bu ölçeklerin yanı sıra öğretmenlerin belirli alanlardaki özyeterliklerini ölçmek için geliştirilen ölçekler de bulunmaktadır (Akkoyunlu, Orhan ve Umay, 2005; B1kmaz, 2002; Ekici, 2005).

Alanyazındaki öğretmen özyeterlik inançlarını ölçmek için geliştirilen ölçme araçlarının genellikle sınıf yönetimi alanındaki özyeterlikler ile sınırlandırıldığı görülmektedir. Ancak öğretmenler bir öğretim lideridir. Sorumlulukları ve etki alanları salt sınıfla sınırlı değildir. Öğretmenler, okulun gelişiminde, meslektaşlarıyla işbirliğinde ve öğretimsel vizyon geliştirmede etkin roller üstlenebilir, yani liderlik sergileyebilirler (Can, 2007; Silva, Gimbert ve Nolan, 2000). Bandura'nın (1997) da belirttiği üzere bu doğrultuda geliştirilecek ölçme aracının öğretmenlerin özyeterlik inançlarının çok boyutlu yapısını yansıtacak şekilde düzenlenmesi gerekmektedir. Öğretmenler, öğretim sürecine ilişkin ve mesleki yeterliklerin yanı sıra sosyal ve entelektüel yeterliklere de sahip olmak durumundadırlar. Dolayısıyla bu araştırmanın amacı, daha önceki ölçme araçlarında ele alınan, öğretmenlerin sınıf yönetiminde, ögretimde ve mesleki uygulamalarındaki özyeterlik inançlarına ek olarak daha kapsamlı bir özyeterlik inanc1 ölçeği geliştirmektir. Bu bağlamda bu çalışmada öğretmenlerin özyeterlik inançları şu alt boyutlarda incelenmiştir: (1) Akademik Özyeterlik, (2) Mesleki Özyeterlik, (3) Sosyal Özyeterlik, (4) Entelektüel Özyeterlik. Bu boyutlar aşağıda kısaca özetlenmiştir:

Akademik özyeterlik. Bu özyeterlik, bireyin kendi öğrenme etkinliklerini düzenleyebilmesi olarak tanımlanabilir (Bandura, 1997). Akademik özyeterlik bir bakıma öğretmenlerin alan bilgisine ilişkin 
özyeterliğini ifade eder. Bu anlamda öğretmenlerin branşına yönelik bilgilerini arttırması, gelişmeleri takip etmesi, hizmet içi eğitimler vermesi ve projeler üretmesi akademik özyeterlik kapsamında ele alınabilir. Dolayısıyla akademik özyeterlik öğretmenlerin kendi alanlarına ilişkin donanımını, bilgi birikimine duydukları güveni ve bunu geliştirmeye yönelik inançlarını ifade eder.

Mesleki özyeterlik. Bu özyeterlik, öğretmenlerin pedagojik, yani meslek bilgisi özyeterliğini ifade etmektedir. Örneğin, öğretmenlerin öğretim ortamını düzenleyebilmesi, zamanı etkili kullanabilmesi, sınıf yönetimini etkili bir biçimde gerçekleştirebilmesi, öğrencilerin motivasyonlarını arttırabilmesi mesleki özyeterlik kapsamında ele alınabilir. Mesleki özyeterlik birçok araştırmada, öğretimsel özyeterlik boyutunu da kapsamaktadır. Bandura (1993), sınıf atmosferinin öğretmenlerin öğretimsel özyeterliğine olan inancından önemli ölçüde etkilediğini belirtmektedir. Nitekim öğretmenlerin ögretimsel özyeterliğinin öğrencilerinin akademik başarılarının belirleyicisi olduğu sonucuna ulaşan araştırmalar bulunmaktadır (Ashton ve Webb, 1986).

Sosyal özyeterlik. Öğretmenlerin olumlu sosyal ilişkiler kurabilme ve kendini ifade etme yeterliğidir. Palancı (2004) sosyal özyeterliği, bir tür sosyal güven olarak ele almaktadır. Sosyal özyeterlik, öğretmenlerin kendilerine destekleyici bir sosyal ortam oluşturulmasını sağlar (Bandura, 1997). Sosyal özyeterliği yüksek öğretmenler, yöneticilerle, velilerle ve meslektaşlarıyla iyi bir iletişim kurabilir, grup içinde düşüncelerini rahatça ifade edebilir ve değişime kolaylıkla uyum sağlayabilir.

Entelektüel özyeterlik. Öğretmenlerin bilgiyi ve olayları anlamlandırma, değerlendirme ve yorumlama gibi bilişsel yeteneklerine dayalı olarak sahip oldukları özyeterliktir. Örneğin öğretmenlerin eğitim sistemini eğitim felsefelerinden yararlanarak değerlendirebilmesi, eğitim sistemindeki güncel gelişmeleri yorumlayabilmesi, olayları bilimsel bir perspektiften değerlendirebilmesi entelektüel özyeterlik içerisinde değerlendirilebilir.

\section{Yöntem}

\section{Örneklem}

Araştırmanın çalışma grubu, Muğla ilinde görev yapan ve araştırmaya gönüllü olarak katılan öğretmenlerden oluşmaktadır. Veriler 2016-2017 eğitim öğretim yılında toplanmıştır. Ölçeğin yap1 geçerliği Açımlayıcı Faktör Analizi (AFA) ve Doğrulayıcı Faktör Analizi (DFA) ile sınanmıştır. AFA ve DFA için iki farklı örneklem grubundan veri toplanmıştır. Birinci örneklem grubundan elde edilen veriler ile AFA, ikinci örneklem grubundan elde edilen veriler ile DFA yapılmıştır. Araştırmada hem AFA hem de DFA için örneklem büyüklügüünde madde sayısının en az beş katı kadar katılımcıya ulaşılması planlanmıştır. Bu çerçevede, AFA için 191, DFA için 285 öğretmenden kullanılabilir veri toplanmıştır. Birinci örneklem grubunda (AFA yapılan) yer alan öğretmenlerin \%52'si kadın $(\mathrm{n}=99)$, $\% 48$ 'i erkektir $(n=92)$. Öğretmenlerin $\% 23$ 'ü $(n=44)$ ilkokullarda, \%34'ü ortaokullarda $(n=65)$, $\% 42.9$ 'u liselerde $(\mathrm{n}=82)$ görev yapmaktadır. Bu gruptaki öğretmenlerin kıdemleri 1 ile 35 yıl arasında değişmektedir. İkinci örneklem grubunda (DFA yapılan) yer alan öğretmenlerin \%55.8'i kadın $(\mathrm{n}=159)$, \%44.2'si erkektir $(\mathrm{n}=126)$. Öğretmenlerin \%26.7'si $(\mathrm{n}=76)$ ilkokullarda, \%43.5' $\mathrm{i}$ ortaokullarda $(\mathrm{n}=124), \% 29.9$ 'u liselerde $(\mathrm{n}=85)$ görev yapmaktadır. Bu gruptaki öğretmenlerin kıdemleri 1 ile 36 yıl arasında değişmektedir.

\section{Veri Toplama Aracının Geliştirilmesi}

Öğretmen Özyeterlik İnancı Ölçeğinin (ÖÖIÖ) geliştirilmesinde alanyazın ayrıntılı olarak taranmış ve bu doğrultuda maddeler yazılmıştır. Ayrıca alanyazında bu konuda daha önce geliştirilmiş ölçeklerden yararlanılmıştır (Bandura, 2006; Cerit, 2010; Çapa vd., 2005; Diken, 2004; Emmer ve Hickman, 1991; Palanc1, 2004; Tschannen-Moran ve Hoy, 2001). Bu çalışma sonunda 52 maddelik bir soru havuzu oluşturulmuştur. Beşli likert tipi yanıt seçenekleri bulunan ölçek, (1) Katılmıyorum, (5) Katılıyorum aralığında yanıtlanmaktadır. Ölçekte ters puanlanan madde bulunmamaktadır. Soru havuzundaki maddeler kapsam geçerliği için öğretim elemanlarından oluşan grubun (4'ü eğitim yönetimi, 3'ü eğitim programları ve öğretim, 1'i ölçme değerlendirme) uzman görüşüne sunulmuş ve gelen öneriler doğrultusunda tekrar düzenlenmiştir. Daha sonra ölçek anlaşılabilirlik ve kolay yanıtlanabilirlik gibi 
özellikleri bakımından 10 öğretmenin görüşüne sunulmuştur. Bu görüşler de dikkate alınarak 41 madde olarak tekrar düzenlenen ölçek, ön deneme için hazır hale gelmiştir.

\section{Verilerin Analizi}

ÖÖIÖ’nün yapı geçerliğini belirlemede öncelikle açımlayıcı faktör analizi (AFA) yapılmış, ardından da söz konusu yapının geçerli bir yapı olup olmadığını belirlemek için doğrulayıcı faktör analizi (DFA) uygulanmıştır. Ölçeğin güvenirliği için, madde toplam korelasyonu, Cronbach's Alfa iç tutarlık katsayısı ve alt ve üst \%27'lik grupların madde ortalama puanları incelenmiştir. Verilerin faktör analizinin gerekliliklerini karşılayıp karşılamadığını belirlemek için dağılımın normalliği ve uç değerler incelenmiştir. Dağılımın normalliğinin belirlenmesinde çarpıklık ve basıklık katsayılarına bakılmıştır. $\mathrm{Bu}$ değerlerin +1 ile -1 araladığında olduğu görülmüş̧ür. Uç değerlerin belirlenmesinde $\mathrm{z}$ ve Mahalanobis uzaklıkları hesaplamıştır. Z değeri +3'ten büyük ve -3 'ten küçük değerler ve .01 anlamlılık düzeyine göre $\chi^{2}$ tablo değerinin üzerindeki Mahalanobis değerleri uç değerler olarak belirlenerek veri setinden çıkarılmıştır.

\section{Bulgular}

Bu bölümde Öğretmen Özyeterlik İnancı Ölçeğinin (ÖÖIÖ) geçerlik ve güvenirlik çalışmasına ilişkin bulgulara yer verilmiştir. Ölçeğin geliştirilmesi sürecinde katılımcılardan toplanan veriler üzerinden önce açımlayıcı ve doğrulayıcı faktör analizi daha sonra güvenirlik analizleri gerçekleştirilmiştir.

\section{Açımlayıcı Faktör Analizine (AFA) İlişkin Bulgular}

Verilerin faktör analizi için uygun olup olmadığını belirlemek için Kaiser Meyer Olkin (KMO) değeri ve Bartlett Küresellik Testi sonuçları incelemiştir. İlk analizde KMO değeri .90 ve Bartlett Küresellik Testi $\left[\mathrm{x}^{2}=4321.10 ; \mathrm{p}=.00\right]$ anlamlı olarak bulunmuştur. $\mathrm{Bu}$ değerler, verilerin faktörleşmeye uygun olduğunu göstermektedir (Büyüköztürk, 2014). Ölçme aracının yapı geçerliğini sağlamak için Açımlayıcı Faktör Analizi (AFA) yapılmıştır. AFA yapılırken temel bileşenler analizi uygulanmıştır. İlk analiz sonrasında ölçek maddelerinin özdeğeri 1'den büyük dokuz faktör altında toplandığ görülmüştür. Bu dokuz faktör toplam varyansın \%65.63'ünü açıklamaktadır. Faktörlerin özdeğerlerine dayanan çizgi grafiği (scree plot) ve her bir faktörün toplam varyansa yaptığı katkı incelenerek ölçeğin dört faktörlü olmasına karar verilmiş ve dört faktörlü yapı üzerinden veriler yeniden analiz edilmiştir. Analiz sonucunda ortaya çıkan faktör yapısı incelenmiş ve bu faktörler "Akademik Özyeterlik", "Mesleki Özyeterlik", "Sosyal Özyeterlik" ve "Entelektüel Özyeterlik" olarak adlandırılmıştır. Maddelerin ölçekte kalmasında faktör yüklerinin .40'dan büyük olması (Şencan, 2005) ve birden fazla faktöre yüksek yük veren maddelerin faktör yükleri arasındaki farkın en az .10 olması ölçütü temel alınmıştır (Büyüköztürk, 2014). Ölçekte yer alan maddelerin faktör yükleri incelendiğinde beş madde (Ö4, Ö5, Ö10, Ö18, Ö34) birden fazla faktöre yüksek yük verdiği için ölçekten çıkarılmıştır. Ayrıca dört madde (Ö6, Ö17, Ö22, Ö31) faktör yük değeri .40'dan küçük olduğu için ve beş madde (Ö15, Ö19, Ö20, Ö32, Ö33) bulundukları faktördeki diğer maddelerle uyumlu olmamaları nedeniyle ölçekten çıkarılmıştır. Madde atılması işlemine öncelikle binişik maddelerden, daha sonra faktör yük değeri daha küçük olandan başlanmıştır. Maddeler ölçekten tek tek çıkarılmış ve her defasında analiz tekrarlanmıştır (Çokluk, Şekercioğlu ve Büyüköztürk, 2012). Maddeler çıkarıldıktan sonra 27 maddeye düşen ölçeğe yeniden AFA uygulanmıştır. Bu işlemde ölçek maddelerinin herhangi bir müdahale gerektirmeden 4 faktörlü bir yapı altında yer aldığı görülmüştür. 27 maddelik ölçek için KMO değeri .89 ve Bartlett Küresellik Testi $\left[\mathrm{x}^{2}=2570.65 ; \mathrm{p}=.00\right]$ anlamlı olarak bulunmuştur. Varimax dik döndürme sonrası elde edilen faktör analizi sonuçları Tablo 1'de verilmiştir. 
Tablo 1. ÖÖIÖ’’nün Açımlayıcı Faktör Analizi Sonuçları

\begin{tabular}{|c|c|c|c|c|c|}
\hline Madde & $\begin{array}{l}\text { Akademik } \\
\text { Özyeterlik }\end{array}$ & $\begin{array}{c}\text { Mesleki } \\
\text { Özyeterlik }\end{array}$ & $\begin{array}{c}\text { Sosyal } \\
\text { Özyeterlik }\end{array}$ & $\begin{array}{l}\text { Entelektüel } \\
\text { Özyeterlik }\end{array}$ & $\begin{array}{c}\text { Ortak } \\
\text { Varyans }\end{array}$ \\
\hline Ö1 & .82 & .14 & .05 & .17 & .71 \\
\hline Ö2 & .82 & .16 & .03 & .05 & .70 \\
\hline Ö3 & .47 & .26 & .27 & .14 & .38 \\
\hline Ö7 & .49 & .29 & .29 & .17 & .44 \\
\hline Ö8 & .54 & .28 & .15 & .25 & .45 \\
\hline Ö9 & .09 & .64 & .16 & .27 & .52 \\
\hline Ö11 & .23 & .71 & .31 & .08 & .66 \\
\hline Ö12 & .13 & .72 & .20 & .11 & .59 \\
\hline Ö13 & .16 & .58 & .32 & .19 & .49 \\
\hline Ö14 & .15 & .71 & .18 & .23 & .61 \\
\hline Ö16 & .28 & .61 & .16 & .19 & .52 \\
\hline Ö21 & .20 & .59 & .21 & .22 & .49 \\
\hline Ö23 & .15 & .35 & .54 & .04 & .43 \\
\hline Ö24 & .07 & .22 & .76 & .00 & .63 \\
\hline Ö25 & .19 & .22 & .70 & .23 & .63 \\
\hline Ö26 & .05 & .19 & .73 & .15 & .59 \\
\hline Ö27 & .13 & .03 & .76 & .20 & .64 \\
\hline Ö28 & .11 & .12 & .77 & .23 & .67 \\
\hline Ö29 & -.04 & .23 & .67 & .04 & .51 \\
\hline Ö30 & .20 & .26 & .58 & .08 & .45 \\
\hline Ö35 & .21 & .03 & .16 & .52 & .34 \\
\hline Ö36 & .05 & .20 & .10 & .78 & .65 \\
\hline Ö37 & -.10 & .20 & .23 & .72 & .61 \\
\hline Ö38 & .16 & .16 & .16 & .78 & .68 \\
\hline Ö39 & .24 & .18 & .02 & .76 & .66 \\
\hline Ö40 & .19 & .15 & .10 & .76 & .64 \\
\hline Ö41 & .07 & .18 & .08 & .72 & .56 \\
\hline $\begin{array}{l}\text { Açıklanan } \\
\text { varyans }\end{array}$ & $\% 9.79$ & $\% 14.43$ & $\% 16.87$ & $\% 15.83$ & $\begin{array}{l}\text { Toplam } \\
\% 56.93\end{array}$ \\
\hline
\end{tabular}

Tablo 1'de görüldüğü gibi, ÖÖiöÖ'nün ilk faktörü olan Akademik Özyeterlik faktöründe beş madde bulunmakta ve bu maddelerin Varimax dik döndürme yöntemiyle döndürülmüş faktör yük değerleri .47 ile .82 arasında değişmektedir. Bu faktörün tek başına açıkladığı varyans \%9.79'dur. Ölçeğin ikinci faktörü olan Mesleki Özyeterlik faktöründe yedi madde bulunmaktadır. Maddelerin faktör yük değerleri .59 ile .72 arasında değişmektedir. Bu faktörün tek başına açıkladığı varyans \%14.43'tür. Ölçeğin üçüncü faktörü olan Sosyal Özyeterlik faktöründe sekiz madde bulunmaktadır. Maddelerin faktör yük değerleri .54 ile .77 arasında değişmektedir. Bu faktörün tek başına açıkladığı varyans \%16.87'dir. Ölçeğin dördüncü faktörü olan Entelektüel Özyeterlik faktöründe yedi madde bulunmaktadır. Maddelerin faktör yük değerleri .52 ile .78 arasında değişmektedir. Bu faktörün tek başına açıkladığ1 varyans \%15.83'tür. Dört faktörün birlikte açıkladığı varyans oranı \%56.93'tür. Sosyal bilimlerde açıklanan varyans oranının çok faktörlü ölçeklerde $\% 40$ ile $\% 60$ arasında olmasının yeterli olduğu ifade edilmektedir (Scherer, Wiebe, Luther ve Adams, 1988 akt. Tavşanc1l, 2005).

\section{Doğrulayıcı Faktör Analizine (DFA) İlișkin Bulgular}

Öğretmen Özyeterlik İnancı Ölçeğinin (ÖÖIOÖ) AFA sonucu dört faktör altında toplanan toplam 27 maddelik yapısına DFA uygulanmıştır. İkinci uygulama öncesi maddeler yeniden numaralandırılmıştır. DFA sonucu elde edilen bulgular değerlendirildiğinde $\chi^{2} / \mathrm{sd}$ oranı $(668.38 / 316) 2.12$ bulunmuştur. DFA ile hesaplanan diğer uyum iyiliği değerleri şöyledir: $\mathrm{GFI}=.85, \mathrm{AGFI}=.82, \mathrm{RMSEA}=.06, \mathrm{RMR}=.03$, SRMR $=.06, \mathrm{CFI}=.97, \mathrm{NFI}=.95, \mathrm{NNFI}=.97$. Bu uyum iyiliği değerlerinin tümü, ÖÖIÖ’nün ölçüm 
modelinin kabul edilebilir bir model olduğunu ortaya koymaktadır (Çelik, 2009; Hair, Black, Babin ve Anderson, 2010; Kline, 2011; Schumacker ve Lomax, 2012; Tabachnick ve Fidell, 2013). Yapilan DFA sonucunda maddelerin standartlaştırılmış faktör yük değerleri $(\lambda i), R^{2}$ ve $t$ değerleri Tablo 2 'de, path diagramı ise ekteki Şekil 1'de yer almaktadır.

Tablo 2. DFA ile Elde Edilen Standartlaştırılmıș Faktör Yükleri $(\lambda i), R^{2}$ ve t değerleri

\begin{tabular}{|c|c|c|c|c|c|}
\hline Faktörler & Madde No & $\begin{array}{l}\text { Standartlaştırılmış } \\
\text { Faktör Yükleri }(\lambda \mathrm{i})\end{array}$ & $\mathbf{R}^{2}$ & $\mathbf{t}$ & $\mathbf{p}$ \\
\hline \multirow{5}{*}{$\begin{array}{l}\text { Akademik } \\
\text { Özyeterlik }\end{array}$} & Ö1 & .52 & .27 & 8.27 & \multirow[t]{5}{*}{.01} \\
\hline & Ö2 & .55 & .30 & 8.80 & \\
\hline & Ö3 & .56 & .31 & 9.01 & \\
\hline & Ö4 & .70 & .49 & 11.84 & \\
\hline & Ö5 & .61 & .37 & 10.00 & \\
\hline \multirow{7}{*}{$\begin{array}{l}\text { Mesleki } \\
\text { Özyeterlik }\end{array}$} & Ö6 & .72 & .52 & 13.39 & \multirow[t]{7}{*}{.01} \\
\hline & Ö7 & .77 & .59 & 14.58 & \\
\hline & Ö8 & .71 & .51 & 13.08 & \\
\hline & Ö9 & .61 & .37 & 10.83 & \\
\hline & Ö10 & .59 & .35 & 10.31 & \\
\hline & Ö11 & .78 & .61 & 14.96 & \\
\hline & Ö12 & .72 & .52 & 13.43 & \\
\hline \multirow{8}{*}{ Sosyal Özyeterlik } & Ö13 & .54 & .29 & 9.33 & \multirow[t]{8}{*}{.01} \\
\hline & Ö14 & .73 & .53 & 13.77 & \\
\hline & Ö15 & .78 & .60 & 15.07 & \\
\hline & Ö16 & .68 & .47 & 12.62 & \\
\hline & Ö17 & .79 & .62 & 15.38 & \\
\hline & Ö18 & .76 & .58 & 14.60 & \\
\hline & Ö19 & .69 & .47 & 12.73 & \\
\hline & Ö20 & .63 & .40 & 11.37 & \\
\hline \multirow{7}{*}{$\begin{array}{l}\text { Entelektüel } \\
\text { Özyeterlik }\end{array}$} & Ö21 & .34 & .12 & 5.70 & \multirow[t]{7}{*}{.01} \\
\hline & Ö22 & .68 & .46 & 12.56 & \\
\hline & Ö23 & .73 & .53 & 13.74 & \\
\hline & Ö24 & .82 & .68 & 16.48 & \\
\hline & Ö25 & .82 & .67 & 16.37 & \\
\hline & Ö26 & .73 & .54 & 13.94 & \\
\hline & Ö27 & .79 & .62 & 15.48 & \\
\hline
\end{tabular}

Tablo 2'deki standartlaştırılmış faktör yük değerleri, gizil değişkenin gözlenen değişkende temsil edilme ağırlı̆̆ını ya da yükünü; $t$ değeri, gizil değişkenlerin gözlenen değişkenleri açıklama oranlarının anlamlılık düzeylerini göstermektedir. Maddelerin standartlaştırılmış faktör yük değerleri .34 ile .82 arasında değişmektedir. Maddelerin t değerleri 5.70 ile 16.48 arasında değişmektedir. Maddelerin tümü için t değerleri .01 düzeyinde anlamlıdır.

\section{Ölçeğin Güvenirliğine İlişkin Bulgular}

Ölçeğin güvenirliği için madde toplam korelasyonları, alt ve üst \%27'lik grupların madde ortalama puanları arasındaki farklar ve Cronbach's Alfa iç tutarlık katsayısı incelenmiştir. Ölçeğin güvenirliğine ilişkin sonuçlar Tablo 3’te sunulmuştur. 
Tablo 3. ÖÖIÖ’nün Güvenirliğine İlişkin Sonuçlar

\begin{tabular}{|c|c|c|c|c|c|c|c|c|}
\hline \multirow[t]{2}{*}{ Faktörler } & \multirow[t]{2}{*}{$\begin{array}{l}\text { Madde } \\
\text { No }\end{array}$} & \multirow[t]{2}{*}{$\begin{array}{c}\text { Madde } \\
\text { Toplam } \\
\text { Korelasyonu }\end{array}$} & \multicolumn{2}{|c|}{$\begin{array}{c}\text { Alt \%27 } \\
(n=52)\end{array}$} & \multicolumn{2}{|c|}{$\begin{array}{c}\text { Üst \%27 } \\
(\mathbf{n}=52)\end{array}$} & \multirow[b]{2}{*}{$\mathbf{t}$} & \multirow[t]{2}{*}{$\begin{array}{c}\text { Cronbach's } \\
\text { Alfa }\end{array}$} \\
\hline & & & AO & $\mathbf{S}$ & AO & $\mathbf{S}$ & & \\
\hline \multirow{5}{*}{$\begin{array}{l}\text { Akademik } \\
\text { Özyeterlik }\end{array}$} & Ö1 & .46 & 3.92 & 0.38 & 4.94 & 0.23 & 16.18 & \multirow[t]{5}{*}{.75} \\
\hline & Ö2 & .39 & 4.07 & 0.33 & 5.00 & 0.00 & 19.92 & \\
\hline & Ö3 & .50 & 3.86 & 0.59 & 4.88 & 0.32 & 10.85 & \\
\hline & Ö4 & .54 & 3.95 & 0.42 & 5.00 & 0.00 & 17.65 & \\
\hline & Ö5 & .52 & 2.98 & 0.72 & 4.69 & 0.46 & 14.28 & \\
\hline \multirow{7}{*}{$\begin{array}{l}\text { Mesleki } \\
\text { Özyeterlik }\end{array}$} & Ö6 & .57 & 3.81 & 0.49 & 4.94 & 0.23 & 14.90 & \multirow[t]{7}{*}{.86} \\
\hline & Ö7 & .64 & 3.76 & 0.50 & 4.94 & 0.23 & 15.07 & \\
\hline & Ö8 & .56 & 3.88 & 0.47 & 4.98 & 0.13 & 16.10 & \\
\hline & Ö9 & .59 & 4.01 & 0.41 & 5.00 & 0.00 & 16.85 & \\
\hline & Ö10 & .61 & 3.50 & 0.64 & 4.90 & 0.29 & 14.31 & \\
\hline & Ö11 & .58 & 3.92 & 0.55 & 4.98 & 0.13 & 13.33 & \\
\hline & Ö12 & .58 & 3.90 & 0.45 & 4.92 & 0.26 & 13.92 & \\
\hline \multirow{8}{*}{$\begin{array}{l}\text { Sosyal } \\
\text { Özyeterlik }\end{array}$} & Ö13 & .52 & 3.78 & 0.53 & 4.82 & 0.38 & 11.37 & \multirow[t]{8}{*}{.88} \\
\hline & Ö14 & .51 & 3.50 & 0.57 & 4.94 & 0.23 & 16.68 & \\
\hline & Ö15 & .66 & 3.61 & 0.56 & 4.92 & 0.26 & 15.05 & \\
\hline & Ö16 & .56 & 4.03 & 0.39 & 5.00 & 0.00 & 17.59 & \\
\hline & Ö17 & .55 & 3.61 & 0.52 & 4.90 & 0.29 & 15.29 & \\
\hline & Ö18 & .61 & 3.63 & 0.52 & 4.96 & 0.19 & 17.09 & \\
\hline & Ö19 & .45 & 3.84 & 0.53 & 4.96 & 0.19 & 14.05 & \\
\hline & Ö20 & .54 & 3.69 & 0.50 & 4.84 & 0.36 & 13.38 & \\
\hline \multirow{8}{*}{$\begin{array}{l}\text { Entelektüel } \\
\text { Özyeterlik }\end{array}$} & Ö21 & .42 & 3.05 & 0.84 & 4.48 & 0.64 & 9.63 & \multirow[t]{7}{*}{.87} \\
\hline & Ö22 & .56 & 3.28 & 0.57 & 4.76 & 0.46 & 14.43 & \\
\hline & Ö23 & .54 & 3.57 & 0.53 & 4.82 & 0.38 & 13.68 & \\
\hline & Ö24 & .61 & 3.26 & 0.66 & 4.90 & 0.29 & 16.27 & \\
\hline & Ö25 & .56 & 3.61 & 0.59 & 4.94 & 0.23 & 14.86 & \\
\hline & Ö26 & .57 & 3.51 & 0.57 & 4.86 & 0.34 & 14.44 & \\
\hline & Ö27 & .51 & 3.42 & 0.60 & 4.71 & 0.49 & 11.84 & \\
\hline & & & & & \multicolumn{3}{|c|}{ Ölçeğin tümü için } & .93 \\
\hline
\end{tabular}

Tablo 3’te görüldüğü gibi, ÖÖİ̈'nün Akademik Özyeterlik faktöründe maddelerin madde-toplam puan korelasyonlarının .39 ile .54 arasında, Mesleki Özyeterlik faktöründe .56 ile .64 arasında, Sosyal Özyeterlik faktöründe .45 ile .66 arasında, Entelektüel Özyeterlik faktörüne .42 ile .61 arasında değiştiği görülmektedir. Madde toplam korelasyonun pozitif ve yüksek olması, maddelerin benzer davranışları örneklediğini ve ölçeğin iç tutarlığının yüksek olduğunu ifade eder. Madde-toplam korelasyonu .30 ve daha yüksek maddelerin bireyleri iyi derecede ayırt ettiği söylenebilir (Büyüköztürk, 2014).

Ölçeğin güvenirlik analizi kapsamında, testin toplam puanlarına göre oluşturulan alt ve üst \%27'lik grupların madde ortalama puanları arasındaki farklar incelenmiştir. Gruplar arasındaki farkların anlamlı çıkması, maddelerin bireyleri ölçülen davranış bakımından ayırt ettiğini göstermektedir (Büyüköztürk, 2014). Yapılan analizde, tüm maddelerin alt ve üst \%27'lik grupları arasındaki fark $\mathrm{p}<.001$ düzeyinde anlamlıdır.

Ayrıca, ölçeğin güvenirliği için Cronbach's Alfa iç tutarlık katsayıları $(\alpha)$ incelenmiştir. Bu katsayı Akademik Özyeterlik faktörü için .75, Mesleki Özyeterlik faktörü için .86, Sosyal Özyeterlik faktörü için .88, Entelektüel Özyeterlik faktörü için .87 ve ölçeğin tümü için .93 olarak hesaplanmıştır. Hesaplanan iç tutarlık katsayıları, ölçeğin güvenirliğinin yüksek olduğunu göstermektedir.

Ölçeğin faktörleri arasındaki ilişkileri incelemek için Pearson korelasyon katsayıları (r) da hesaplanmıştır. Yapılan analizde, Akademik Özyeterlik ile Mesleki Özyeterlik $(r=.60)$, Sosyal 
Özyeterlik ( $(\mathrm{r}=.46)$ ve Entelektüel Özyeterlik $(\mathrm{r}=.45)$ arasında orta düzeyde pozitif, Mesleki Özyeterlik ile Sosyal Özyeterlik $(\mathrm{r}=.60)$ ve Entelektüel Özyeterlik $(\mathrm{r}=.51)$ arasında orta düzeyde pozitif, ve benzer şekilde Sosyal Özyeterlik ile Entelektüel Özyeterlik $(r=.40)$ arasında orta düzeyde pozitif ilişkiler bulunmaktadir.

\section{Sonuç ve Öneriler}

Bu çalışmada öğretmenlerin özyeterlik inançlarını belirlemede kullanılabilecek geçerli ve güvenilir bir veri toplama aracının geliştirilmesi amaçlanmıştır. Başlangıçta 52 madde olarak hazırlanmış olan Öğretmen Özyeterlik İnancı Ölçeği'nden (ÖÖ̈IÖ) uzman görüşünden sonra 11 madde çıkarılmış ve bazı düzeltmeler yapılmıştır. $\mathrm{Bu}$ aşamadan sonra, 41 maddelik ölçek öğretmenlerden oluşan örneklem grubuna uygulanmış ve elde edilen veriler üzerinden ölçeğin geçerlik ve güvenirlik analizleri yapılmıştır. AFA sonucunda, başlangıçta ölçek maddelerinin 9 faktör altında toplandığı görülmüştür. Ancak çizgi grafiği, her bir faktörün toplam varyansa yaptığı katkı ve faktörlerin açıklanabilirlik özelliği dikkate alınarak ölçeğin dört faktörlü olması gerektiğine karar verilmiş ve analiz tekrarlanmıştır. Faktörler "Akademik Özyeterlik", "Mesleki Özyeterlik", "Sosyal Özyeterlik" ve "Entelektüel Özyeterlik" olarak adlandırılmıştır. Düşük faktör yük değerine sahip olan 4 madde, birden fazla faktörde yüksek faktör yük değerine sahip olan 5 madde ve bulundukları faktördeki diğer maddelerle uyumlu olmayan 5 madde ölçekten çıkarılmış ve ölçek 27 maddeye düşmüştür. Ölçekten maddeler tek tek atılmış ve madde atılmasının ardından her defasında analiz tekrarlanmıştır.

ÖÖïÖ’nün Akademik Özyeterlik faktöründe yer alan maddelerin faktör yük değerleri .47 ile .82, madde toplam korelasyonları .39 ile .54; Mesleki Özyeterlik faktöründe faktör yük değerleri .58 ile .72, madde toplam korelasyonları .56 ile .64; Sosyal Özyeterlik faktöründe faktör yük değerleri .54 ile .77, madde toplam korelasyonları .45 ile .66; Entelektüel Özyeterlik faktöründe faktör yük değerleri .52 ile .78, madde toplam korelasyonları .42 ile .61 arasında değişmektedir. Akademik Özyeterlik faktörünün tek başına açıkladığ 1 varyans \%9.79, Mesleki Özyeterlik faktörünün \%14.43 Sosyal Özyeterlik faktörünün \%16.87 ve Entelektüel Özyeterlik faktörünün \%15.83'tür. Dört faktörün birlikte açıkladığı varyans oranı ise \%56.93'tür. Faktörlerin Cronbach's Alfa iç tutarlık katsayıları; Akademik Özyeterlik faktörü için .75, Mesleki Özyeterlik faktörü için .86, Sosyal Özyeterlik faktörü için .88, Entelektüel Özyeterlik faktörü için .87 ve ölçeğin tümü için .93 olarak hesaplanmıştır. Alt ve üst \%27'lik grupların madde ortalamaları incelenmiş ve tüm maddelerin ayırt ediciliklerinin $\mathrm{p}<.001$ düzeyinde anlamlı olduğu görülmüştür.

Ölçeğin AFA sonucunda dört faktör altında toplanan 27 maddelik yapısına DFA uygulanmıştır. DFA ile hesaplanan uyum iyiliği değerleri şöyledir: $\chi^{2} / \mathrm{sd}=2.12$, GFI $=.85$, AGFI $=.82$, RMSEA $=.06$, $\mathrm{RMR}=.03, \mathrm{SRMR}=.06, \mathrm{CFI}=.97, \mathrm{NFI}=.95, \mathrm{NNFI}=.97$. Elde edilen uyum indeksleri modelin geçerli bir model olduğunu göstermektedir. Böylece söz konusu yapının doğrulandığına karar verilmiştir.

Sonuç olarak Öğretmen Özyeterlik İnancı Ölçeğinin nihai formu 27 maddeden oluşmakta ve maddeler (1) Katılmıyorum, (5) Katılıyorum aralığında puanlanmaktadır. Ölçeğin "Akademik Özyeterlik" faktöründe beş, "Sosyal Özyeterlik" faktöründe sekiz, "Entelektüel Özyeterlik" ve "Mesleki Özyeterlik" faktöründe yedi madde bulunmaktadır. Ölçekte ters puanlanan madde bulunmamaktadır. Ölçekte her bir faktörden ve ölçeğin tümünden toplam puan alınabilmektedir. Her bir faktörden ya da ölçeğin tümünden alınan puanların artması, öğretmenlerin o faktöre yönelik özyeterlik inançlarının arttı̆̆ını göstermektedir. Örneğin akademik özyeterlik faktöründen alınan yüksek puan, öğretmenlerin daha fazla akademik özyeterlik inancına sahip olduğu şeklinde yorumlanabilir.

Alanyazındaki öğretmen özyeterlik inançlarını ölçmek için geliştirilen ölçme araçları genellikle öğretmenlerin sınıf yönetimi alanındaki özyeterlikleri ile sınırlandırılmıştır. Ayrıca birçok ölçme aracında akademik ve mesleki özyeterliğin bir arada ya da birbirinin yerine kullanıldığı görülmektedir. Birçok benzer ölçme aracından farklı olarak bu çalışmada geliştirilen ölçekle, öğretmenlerin sosyal ve entelektüel özyeterlikleri de ölçülebilmektedir. Öğretmen Özyeterlik İnancı Ölçeğinin geçerlik ve güvenirliğine ilişkin bulgular birlikte değerlendirildiğinde, ölçeğin öğretmenlerin özyeterlik inançlarının ölçümünde kullanılabilecek geçerli ve güvenilir bir araç olduğu ifade edilebilir. Elde edilen bulgulara dayanarak, bu çalışma kapsamında geliştirilen ölçme aracının ilgili alanyazındaki önemli bir 
eksikliği gidereceği ve psikometrik nitelikleri yeterli olduğu için bundan sonraki çalışmalarda kullanılabileceği söylenebilir.

\section{Kaynakça}

Akkoyunlu, B., Orhan, F., \& Umay, A. (2005). Bilgisayar öğretmenleri için bilgisayar öğretmenliği özyeterlik ölçeği. Hacettepe Üniversitesi Ë̆itim Fakültesi Dergisi, 29, 1-8.

Ashton, P. T., \& Webb, R. B. (1986). Making a difference: Teachers' sense of efficacy and student achievement. White Plains, NY: Longman.

Bandura, A. (1977). Self-efficacy: Toward a unifying theory of behavioral change. Psychological Review, 84(2), 191-215.

Bandura, A. (1986). Social foundations of thought and action: A social cognitive theory. Englewood Cliffs, N. J: Prentice-Hall.

Bandura, A. (1993). Perceived self-efficacy in cognitive development and functioning. Educational Psychologist, 28(2), 117-148.

Bandura, A. (1997). Self-efficacy: The exercise of control. New York: Freeman.

Bandura, A. (2006). Guide for constructing self-efficacy scales. Self-efficacy Beliefs of Adolescents, $5(307-337)$.

Bıkmaz, F. H. (2002). Fen öğretiminde öz-yeterlik inancı ölçeği. Eğitim Bilimleri ve Uygulama, 1(2), $197-210$.

Büyüköztürk, Ş. (2014). Sosyal bilimler için veri analizi el kitabı. Ankara: Pegem Akademi.

Can, N. (2007). Öğretmen liderliği becerileri ve bu becerilerin gerçekleştirilme düzeyi. Erciyes Üniversitesi Sosyal Bilimler Enstitü Dergisi, 22(1), 263-288.

Cerit, Y. (2010). Teacher efficacy scale: The study of validity and reliability and preservice classroom teachers' self efficacy beliefs. Journal of Theory and Practice in Education, 6(1), 68-85.

Çapa, Y., Çakıroğlu, J., \& Sarıkaya, H. (2005). The development and validation of a Turkish version of teachers' sense of efficacy scale. Eğitim ve Bilim, 30(137), 74-81.

Çelik, A. H. (2009). Yapısal eşitlik modellemesi ve bir uygulama: Genişletilmiş online alışveriş kabul modeli. (Yayımlanmamış Doktora Tezi). Eskişehir Osmangazi Üniversitesi, Fen Bilimleri Enstitüsü, Eskişehir.

Çokluk, Ö., Şekercioğlu, G., \& Büyüköztürk, Ş. (2012). Sosyal bilimler için çok değişkenli istatistik SPSS ve LISREL uygulamalart. Ankara: Pegem Akademi.

Dellinger, A. B., Bobbett, J. J., Olivier, D. F., \& Ellet C. D. (2008). Measuring teachers' self- efficacy beliefs: Development and use of the TEBS-Self. Teaching and Teacher Education, 24(3), 751766.

Diken, İ. H. (2004). Öğretmen yeterlik ölçeği: Türkçe uyarlaması, geçerlik ve güvenirlik çalışması. Eurasian Journal of Educational Research (EJER), 16, 102-112.

Ekici, G. (2005). Biyoloji öz-yeterlik ölçeğinin geçerlik ve güvenirliği. Hacettepe Üniversitesi Eğitim Fakültesi Dergisi, 29, 85-94.

Emmer, E. T., \& Hickman, J. (1991). Teacher efficacy in classroom management and discipline. Educational and Psychological Measurement, 51(3), 755-765.

Gibson, S., \& Dembo, M. H. (1984). Teacher efficacy: A construct validation. Journal of Educational Psychology, 76(4), 569-582.

Guskey, T. R., \& Passaro, P. D. (1994). Teacher efficacy: A study of construct dimensions. American Educational Research Journal, 31, 627-643. 
Hair, J. F., Black, W. C., Babin, B., Anderson, R. E., \& Tatham, R. L. (2010). Multi- variate data analysis (7th ed). Upper Saddle River, NJ: Prentice-Hall.

Kline, R. B. (2011). Principles and practice of structural equation modeling. London: Guilford publications.

Lunenburg, F. C. (2011). Self-efficacy in the workplace: Implications for motivation and performance. International Journal of Management, Business, and Administration, 14(1), 1-6.

Palanc1, M. (2004). Üniversite ögrencilerinin sosyal kaygı problemlerini açılama ve gidermeye yönelik gerçeklik terapisi oryantasyonlu bir yardım programının geliştirilmesi. (Yayımlanmamış, Doktora Tezi). Karadeniz Teknik Üniversitesi, Sosyal Bilimler Enstitüsü, Trabzon.

Schumacker, R. E., \& Lomax, R. G. (2012). A beginner's guide to structural equation modeling. New York, NY: Routledge Academic.

Silva, D. Y., Gimbert, B ve Nolan, J. (2000). Sliding the doors: Locking and unlocking possibilities for teacher-leadership. Teachers College Record, 102(4), 779-804.

Stajkovic, A. D., \& Luthans, F. (2002). Social cognitive theory and self-efficacy: Implications for motivation theory and practice. In R. M. Steers, L. W. Porter, \& G. A. Bigley (Eds.), Motivation and Work Behavior (7th ed.), 126-140. NY: McGraw-Hill.

Şencan, H. (2005). Sosyal ve davranışsal ölçümlerde güvenilirlik ve geçerlilik. Ankara: Seçkin.

Tabachnick, B. G., \& Fidell, L.S. (2013). Using multivariate statistics. (6th ed.). Boston: Ally and Bacon.

Taşkın, Ç. Ş., \& Hacıömeroğlu, G. (2010). Öğretmen özyeterlik inanç ölçeğinin Türkçeye uyarlanması ve sınıf öğretmeni adaylarının özyeterlik inançları. Buca Eğitim Fakültesi Dergisi, 27, 63-75.

Tavşancıl, E. (2005). Tutumların ölçülmesi ve SPSS ile veri analizi. Ankara: Nobel.

Tschannen-Moran, M., \& Hoy, A. W. (2001). Teacher efficacy: Capturing an elusive construct. Teaching and Teacher Education, 17(7), 783-805. 


\section{EK 1. Öğretmen Özyeterlik İnancı Ölçeği Path Diyagramı}

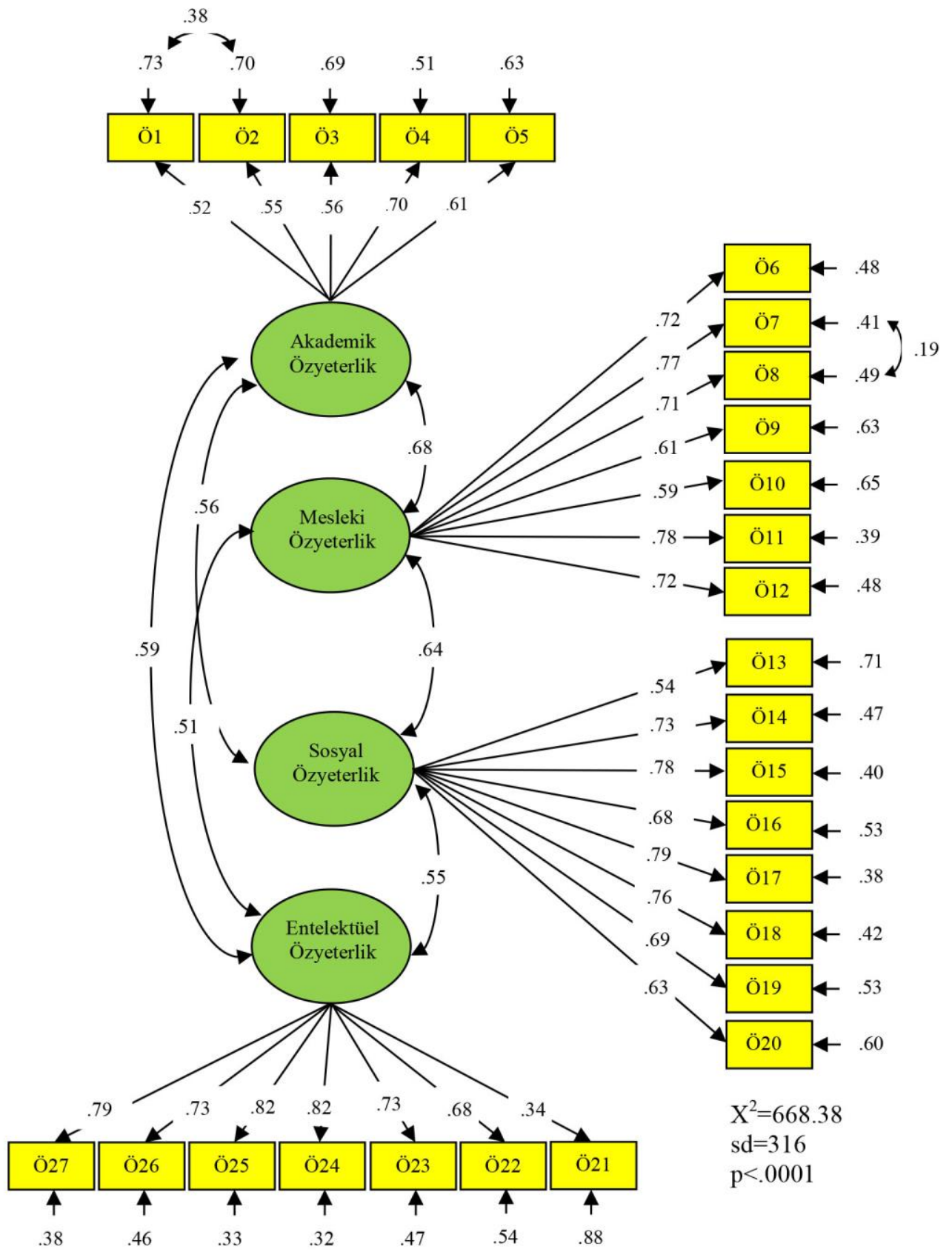




\section{EK 2.}

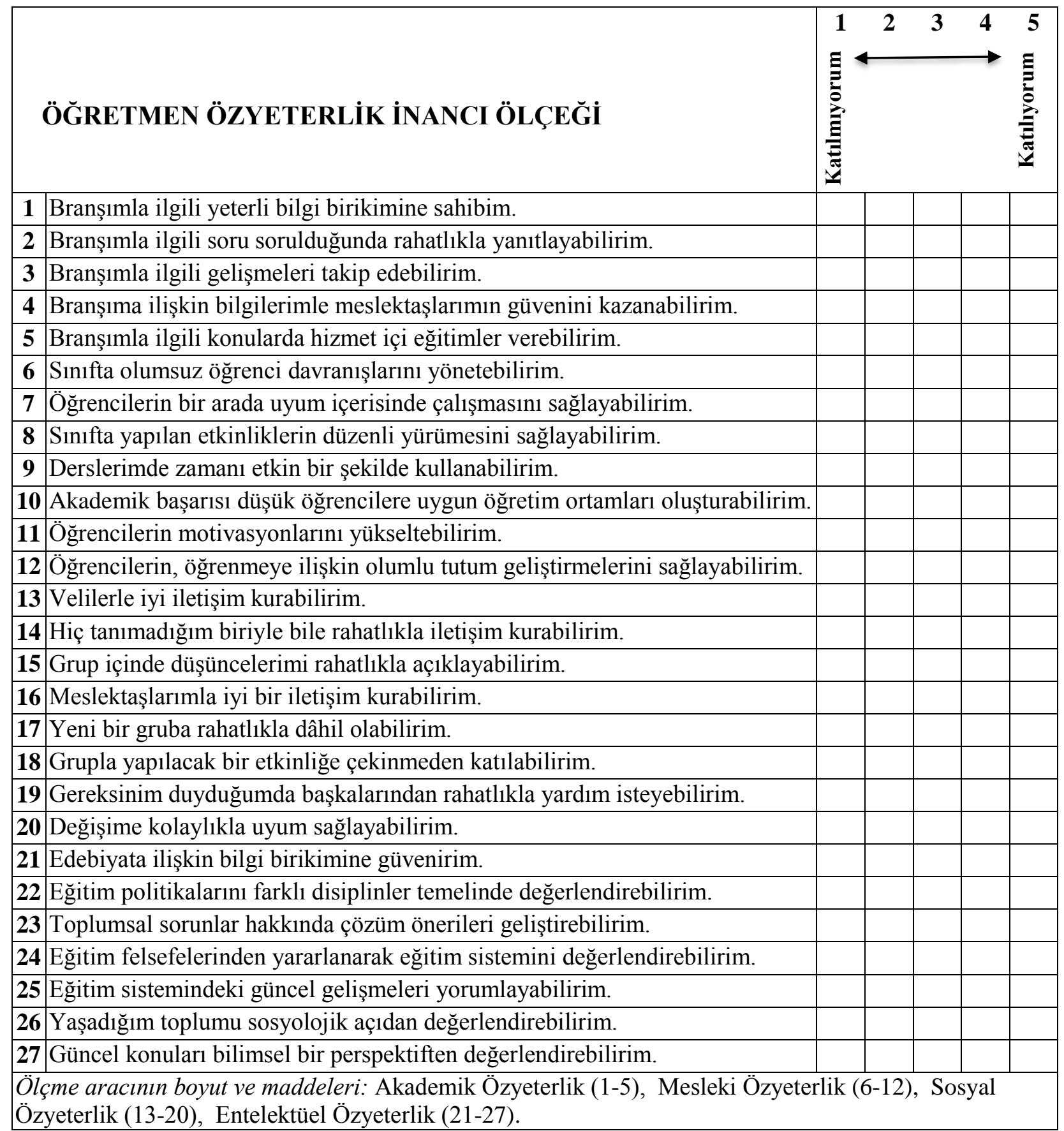

